\title{
Practices Implemented by DOE Better Plants Program Partners to Mitigate COVID-19
}

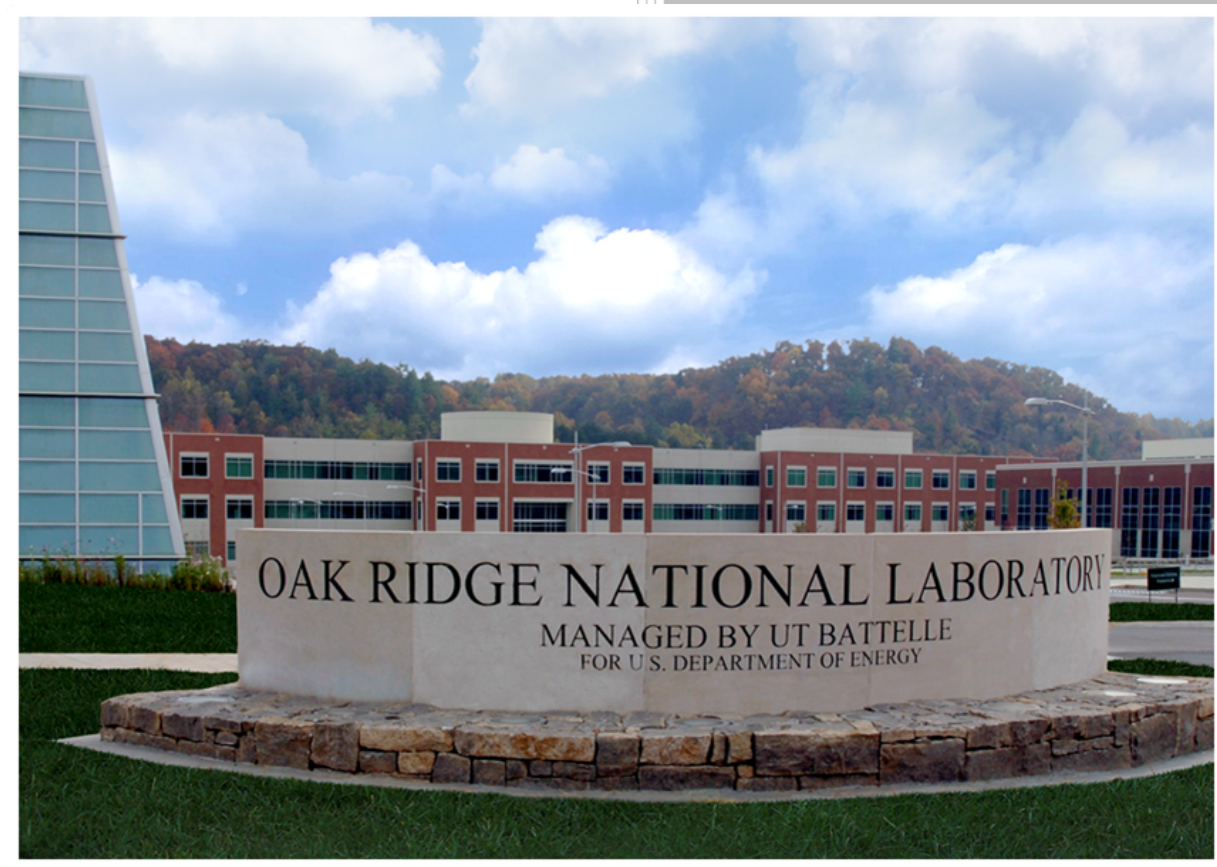

Approved for public release.

Distribution is unlimited.

Wei Guo

Thomas Wenning Sachin Nimbalkar

Eli Levine

Bruce Lung

October 2020 


\section{DOCUMENT AVAILABILITY}

Reports produced after January 1, 1996, are generally available free via US Department of Energy (DOE) SciTech Connect.

Website www.osti.gov

Reports produced before January 1, 1996, may be purchased by members of the public from the following source:

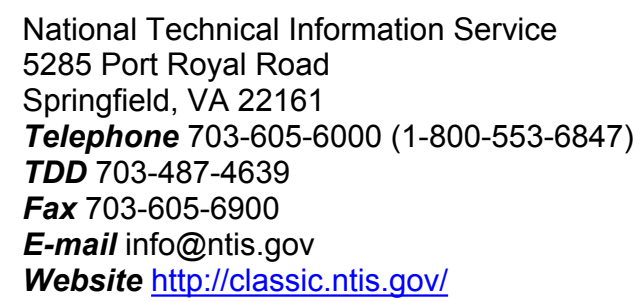

Reports are available to DOE employees, DOE contractors, Energy Technology Data Exchange representatives, and International Nuclear Information System representatives from the following source:

Office of Scientific and Technical Information

PO Box 62

Oak Ridge, TN 37831

Telephone 865-576-8401

Fax 865-576-5728

E-mail reports@osti.gov

Website http://www.osti.gov/contact.html

This report was prepared as an account of work sponsored by an agency of the United States Government. Neither the United States Government nor any agency thereof, nor any of their employees, makes any warranty, express or implied, or assumes any legal liability or responsibility for the accuracy, completeness, or usefulness of any information, apparatus, product, or process disclosed, or represents that its use would not infringe privately owned rights. Reference herein to any specific commercial product, process, or service by trade name, trademark, manufacturer, or otherwise, does not necessarily constitute or imply its endorsement, recommendation, or favoring by the United States Government or any agency thereof. The views and opinions of authors expressed herein do not necessarily state or reflect those of the United States Government or any agency thereof. 
Energy and Transportation Science Division

\title{
PRACTICES IMPLEMENTED BY DOE BETTER PLANTS PROGRAM PARTNERS TO MITIGATE COVID-19
}

\author{
Wei Guo (Oak Ridge National Laboratory) \\ Thomas Wenning (Oak Ridge National Laboratory) \\ Sachin Nimbalkar (Oak Ridge National Laboratory) \\ Eli Levine (US Department of Energy) \\ Bruce Lung (Boston Government Services LLC)
}

Date Published: October 2020

Prepared by

OAK RIDGE NATIONAL LABORATORY

Oak Ridge, TN 37831-6283

managed by

UT-BATTELLE, LLC

for the

US DEPARTMENT OF ENERGY

under contract DE-AC05-00OR22725 



\section{CONTENTS}

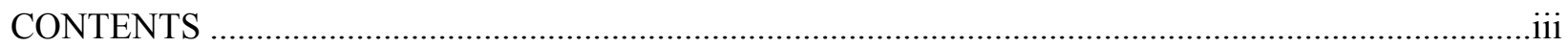

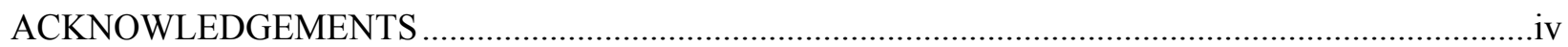

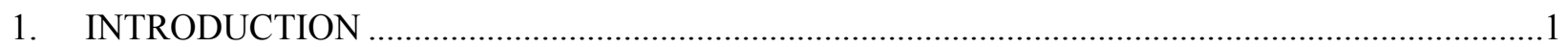

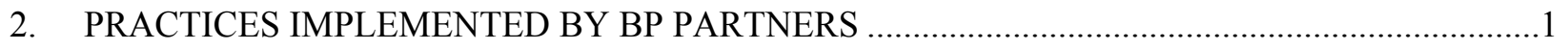

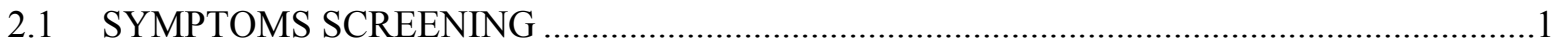

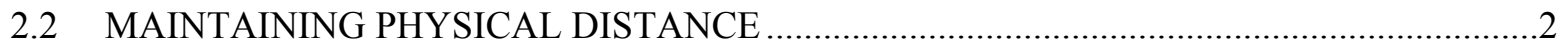

2.2.1 Production Management ..............................................................................

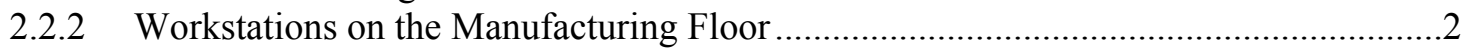

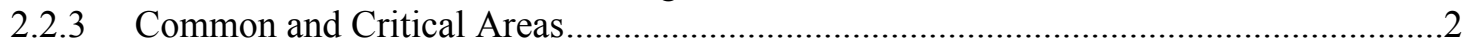

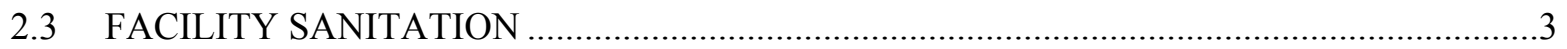

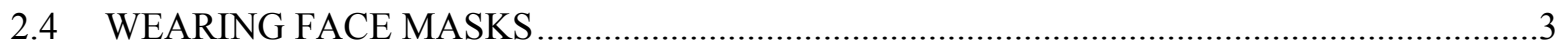

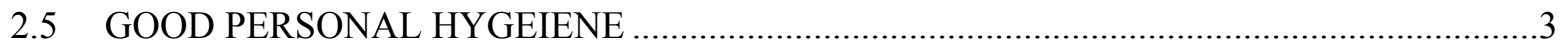

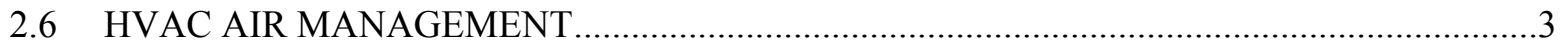

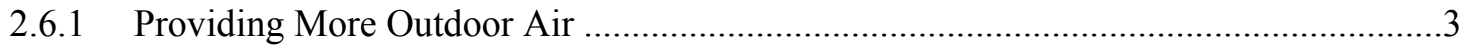

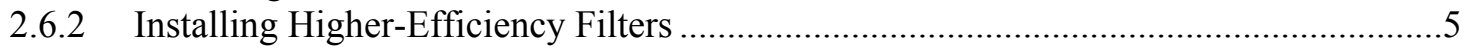

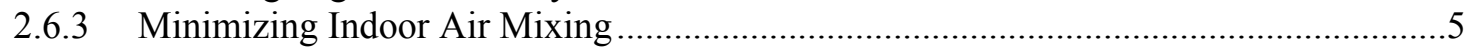

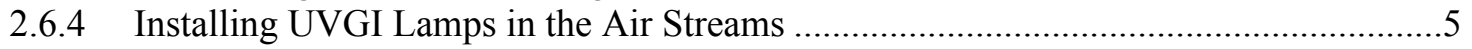

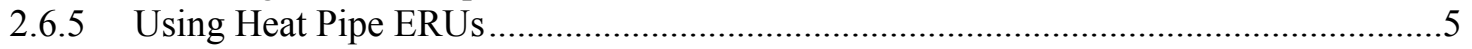

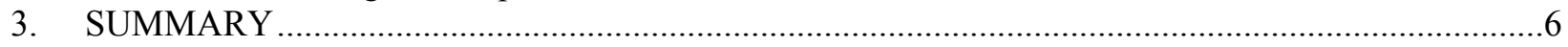

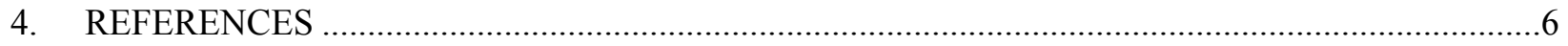




\section{ACKNOWLEDGEMENTS}

This work was supported by the Advanced Manufacturing Office of the US Department of Energy. The authors appreciated all the valuable contribution from the Better Plants program partners and program staff. Without the participation of these industry leaders, this document would not have been possible.

The authors also would like to thank Mahabir Bhandari and Jennifer Travis of Oak Ridge National Laboratory for their valuable review comments and editorial work on this report. 


\section{INTRODUCTION}

Since the coronavirus disease 2019 (COVID-19) broke out in the United States in January 2020, many nonessential manufacturing plants temporarily closed to follow the guidance from federal and local governments, but the plants making critical medical protective gear and life essentials have kept running at $100 \%$ or even higher rates of their capacities. As the spread of COVID-19 started to slow in some areas, more and more plants began gradually restarting production activities. One major challenge facing manufacturing facilities during this pandemic is how to keep workers safe without interrupting production.

The US Department of Energy (DOE) Better Plants (BP) program is a voluntary program launched in 2011 to improve the energy efficiency of industrial facilities and water and wastewater treatment plants. As of October 2020, 235 manufacturing companies and public water and wastewater treatment municipalities have partnered with the BP program [1]. By partnering with the BP program, partners pledge long-term ambitious energy efficiency improvement goals, typically $20 \%$ to $25 \%$ savings over 10 years. The technical account managers of the BP program work with partners on a regular basis to provide technical support and national recognitions for their achievements.

Since COVID-19 first broke out, BP program technical account managers have been discussing the impact of this pandemic with partners. At the Better Buildings, Better Plants Summit 2020 (June 8-11), 15 breakout sessions with more than 200 attendees were held to discuss practices that they had implemented to follow the guidance from federal and local government agencies while maintaining productivity. This report is intended to share these practices and to provide energy impact information of some practices.

Attendees also discussed the challenges they were facing with energy management and what they were seeing both at their plants and on a corporate level during the pandemic. These challenges and potential solutions were published separately [2].

\section{PRACTICES IMPLEMENTED BY BP PARTNERS}

\subsection{SYMPTOMS SCREENING}

Partners mentioned that the first and foremost protective action is to screen for symptoms and prevent potentially sick visitors or workers from entering a facility. Face masks, face shields, and/or protective gowns are provided to symptom screeners. Visual signs (e.g., floor markings) are furnished as a reminder to maintain at least 6-ft distance while visitors and workers are waiting in line for screening.

In partner facilities when workers with symptoms are identified, human resources departments and supervisors are informed so that the workers' sick leaves can be properly handled, and work shifts can be rescheduled. Workers with symptoms are then typically encouraged to contact health care providers for further guidance.

For many partners, body temperatures of visitors and workers are checked before entry into the facility to identify anyone with a fever of $100.4^{\circ} \mathrm{F}$ or greater. Noncontact full-body thermal scanners and infrared thermometers are preferred by partners. Several partners were noted for providing personal thermometers to all employees to do home checks each morning.

Partners also mentioned that they screen for other symptoms including cough, shortness of breath, chills, muscle pain, headache, sore throat, recent loss of taste or smell, and others. As an example, verbal or written questionnaires are provided by partners at the entry to determine whether visitors and workers 
have had any symptoms in the past 24 hours and whether and where they have travelled in the past two weeks.

\subsection{MAINTAINING PHYSICAL DISTANCE}

Nearly all partners have implemented increased physical distances between workers to $6 \mathrm{ft}$ or more at all times to keep workers out of the travel path of infectious droplets and, therefore, to reduce the chance of the virus spread among workers.

\subsubsection{Production Management}

Staggering the shift starting times is a tactic that has been adopted by partners to avoid possible crowds at the entry and exit points within plant buildings. Some partners noted that they have also reduced the number of employees per shift but added or extended the length of shifts so that physical distance is increased in each shift. Most partners mentioned that when one positive case was identified, the whole work area or division was shut down and underwent a deep cleaning.

A common theme across partners is that employees have been told to work remotely if their presence at the facility is not required for production. Many partners noted that only business-essential contractors and vendors are allowed into the facility and are required to use separate breakrooms and bathrooms. No commercial travel is allowed unless business essential.

\subsubsection{Workstations on the Manufacturing Floor}

Many partners have rearranged workstations to maintain at least 6-ft distance in all directions (side to side and face to face). Some partners mentioned installing separation media, such as strip curtains or plexiglass shields, along production lines to break down the travel path of infectious droplets. This has enabled multiple people to work on the assembly lines largely as they used to do.

\subsubsection{Common and Critical Areas}

Partners provided feedback on steps being taken in a variety of common and critical areas, including:

Offices: Big open-space offices are modified to cubicles with tall dividers. The cubicle settings are also designed to maintain social distance.

Cafeterias: Workers are encouraged to bring their own lunch. Cafeterias are closed except for some grab-and-go shelves.

Conference rooms: The number of people within conferences is limited and tracked. Nonessential inperson meetings are discouraged.

Hallways and stairs: Visual floor-and wall-markings are used to make one-way traffic and maintain $6 \mathrm{ft}$ between pedestrians. When one-way traffic is not feasible, opposite traffic is kept at least $6 \mathrm{ft}$ apart.

Critical spaces: For example, in control rooms, only critical operators are allowed and the number of people within is tracked and limited to the bare minimum.

Water fountains: Manual water fountains are being removed and replaced with noncontact bottle-filling water fountains. 


\subsection{FACILITY SANITATION}

To minimize the touching of surfaces, partners were noted for leaving some light fixtures on at all times and changing light switches to occupancy sensors or scheduled timer controls. Other examples include leaving doors open at all times to avoid the use of door handles or installing door foot pulls as an alternative to opening unlatched doors. Cautions were noted in these practices due to some doors serve as the barriers between different thermal and pressurized zones and keeping them open might impair the thermal and pressurization status of some zones.

Most partners said that the surfaces of tools, workstations, office desks, and break room tables were sanitized after each shift or use. In addition, door handles and handrails were also frequently sanitized.

\subsection{WEARING FACE MASKS}

Most partners have required workers to wear face masks in more populated areas. Many partners consult qualified internal and external experts on the appropriate face mask types for various work conditions.

\subsection{GOOD PERSONAL HYGEIENE}

Many partners believe that good personal hygiene is the foundation of what everyone can do to slow down the virus spread and keep workers safe. Most are noted for placing hand sanitizing stations at multiple convenient locations to encourage hand hygiene. Touch-free hand sanitizer and hand-washing stations are preferred by partners.

In many partner facilities workers are often reminded by visual signs to avoid touching their faces, including their eyes, noses, and mouths, particularly after their work and taking off personal protective equipment. Partners encourage workers to use a tissue to cover their cough or sneeze and then throw the tissue into a trash can and wash their hands thoroughly.

\subsection{HVAC AIR MANAGEMENT}

Partners were noted for having implemented the following HVAC air control strategies to reduce the risks of infectious aerosol dissemination: providing more outdoor air, implementing higher-efficiency filters, minimizing indoor air mixing, installing ultraviolet germicidal irradiation (UVGI) lamps in the airstream, and using heat pipe energy-recovery units (ERUs) instead of enthalpy wheels.

\subsubsection{Providing More Outdoor Air}

Many partners mentioned that they have reconfigured HVAC systems to provide $100 \%$ outdoor air when possible. In addition, air change rates are increased for certain spaces to further dilute the virus concentration. Partners noted inspecting the operation of outdoor air dampers to ensure the outdoor air intake. Some stated that when $100 \%$ outdoor air cannot be provided all the time, outdoor air is used to flush the whole facility after each shift. Closely monitoring the space conditions and the operation of manufacturing equipment during hot and cold seasons is a good practice.

Energy Note: $100 \%$ outdoor air and higher air change rates require more energy to satisfy the heating and cooling loads from spaces and manufacturing processes depending on the facility's location. The sensible and latent loads for heating and cooling are estimated for all 15 climate zones are estimated using TMY3 weather data and are presented in Table 1; the estimated loads are for cooling outdoor air to the 
conditions of $75^{\circ} \mathrm{F}$ dry-bulb temperature with $50 \%$ relative humidity and the sensible loads for heating outdoor air to $70^{\circ} \mathrm{F}$ dry-bulb temperature.

Sensible cooling load, latent cooling load, and sensible heating load per CFM of outdoor air for any given hour are estimated using Equation (1), (2), and (3), respectively.

Sensible cooling load $=\frac{(\text { outdoor air drybulb temp }-75 F)^{+} \times 1.08}{12000}$

Latent cooling load $=\frac{\left(\text { outdoor air humidity ratio }-\frac{65 g r}{l b}\right)^{+} \times 4.5 \times 1050}{7000 \times 12000}$

Sensible heating load $=\frac{(70 F-\text { outdoor air drybulb temp })^{+} \times 1.08}{1000}$

Note:

a. 1.08 is the specific heat (Btu/CFM) of air at standard temperature and pressure.

b. $65 \mathrm{gr} / \mathrm{lb}$ is the humidity ratio of air at the condition of $75^{\circ} \mathrm{F}$ dry-bulb temperature with $50 \%$ relative humidity.

c. 4.5 is the mass (lbs) of air per hour per CFM.

d. 7,000 is the conversion factor from pounds of water to grains.

e. 1,050 is the energy $(\mathrm{Btu} / \mathrm{lb})$ of vaporization of water at standard temperature and pressure.

f. 12,000 is the conversion factor from cooling tons to Btu/hr.

g. 1,000 is the conversion factor from $\mathrm{kBtu}$ to Btu.

h. The superscript ${ }^{+}$notation indicates that the value of the parenthetic term is zero when the value of the term enclosed by the parentheses is negative.

Table 1 Cooling and Heating Loads from Outdoor Air for 15 Climate Zones

\begin{tabular}{|c|c|c|c|c|c|}
\hline \multirow{2}{*}{ ASHRAE Climate Zones } & \multirow{2}{*}{ City, State } & \multicolumn{3}{|c|}{$\begin{array}{c}\text { Cooling Load } \\
\text { (Ton-hours/CFM-yr) }\end{array}$} & $\begin{array}{c}\text { Sensible Heating } \\
\text { Load } \\
\text { (kBtu/CFM-yr.) }\end{array}$ \\
\cline { 3 - 5 } & & Latent & Sensible & Total & 12.6 \\
\hline Zone 1A (hot, humid) & Miami, FL & 18.4 & 3.0 & 21.3 & 63.1 \\
\hline Zone 2A (hot, humid) & Houston, TX & 12.8 & 2.3 & 15.1 & 50.2 \\
\hline Zone 2B (hot, dry) & Phoenix, AZ & 1.5 & 5.9 & 7.4 & 106.9 \\
\hline Zone 3A (hot, humid) & Memphis, TN & 7.5 & 1.8 & 9.3 & 95.0 \\
\hline Zone 3B (hot, dry) & El Paso, TX & 2.1 & 2.1 & 4.2 & 126.4 \\
\hline Zone 3C (marine) & San Francisco, CA & 0.2 & 0.05 & 0.20 & 155.2 \\
\hline Zone 4A (mild, humid) & Baltimore, MD & 4.5 & 0.9 & 5.3 & 149.8 \\
\hline Zone 4B (mild, dry) & Albuquerque, NM & 0.8 & 1.1 & 1.9 & 160.8 \\
\hline Zone 4C (marine) & Seattle, WA & 0.2 & 0.1 & 0.3 & 184.5 \\
\hline Zone 5A (cold, humid) & Chicago, IL & 3.2 & 0.8 & 4.0 & 186.1 \\
\hline Zone 5B (cold, dry) & Boise, ID & 0.03 & 0.9 & 0.89 & 232.7 \\
\hline Zone 6A (cold, humid) & Burlington, VT & 1.8 & 0.2 & 2.0 & 245.7 \\
\hline Zone 6B (cold, dry) & Helena, MT & 0.0 & 0.4 & 0.4 & 294.4 \\
\hline Zone 7 (very cold) & Duluth, MN & 1.3 & 0.1 & 1.4 & 362.1 \\
\hline Zone 8 (extremely cold) & Fairbanks, AK & 0.04 & 0.01 & 0.05 & \\
\hline
\end{tabular}




\subsubsection{Installing Higher-Efficiency Filters}

Partners stated that where $100 \%$ outdoor air is not a feasible option, MERV 13 ( $>90 \%$ efficiency for 3-10 $\mu \mathrm{m}$ particles) or 16 ( $>95 \%$ efficiency for 3-10 $\mu \mathrm{m}$ particles) and high-efficiency particulate air (HEPA) filters ( $>99.97 \%$ efficiency for $0.3 \mu \mathrm{m}$ particles) are installed to replace MERV 8 ( $>70 \%$ efficiency for $3-$ $10 \mu \mathrm{m}$ particles) in central air-handling units. HEPA and high-MERV filters are also used in some portable room air cleaners. In addition, the gaps between filters and the frame are regularly inspected by partners to minimize the air bypass.

Energy Note: The capacities of fans and motors need to be carefully examined to ensure their proper operation and sufficient air flow is provided to satisfy thermal loads. For the same filter depth, MERV 13 filters can cause 0.1 in w.g. or higher more pressure loss than MERV 8 filters [3]. HEPA filters can cause 0.5 in w.g. or higher more pressure loss than MERV 13 [4]. A good rule of thumb is that, given the electricity rate of $\$ 0.1 / \mathrm{kWh}$ and the load factor of $90 \%$, the annual energy cost penalty is about $\$ 15 / 1,000$ CFM for 0.1 in w.g. pressure loss.

\subsubsection{Minimizing Indoor Air Mixing}

Partners commonly mentioned turning off personal spot-cooling fans and large ceiling fans to minimize indoor air mixing. In several cases, partners reversed the direction of large ceiling fans to draw air up away from workers on the plant floor.

Energy Note: Turning off spot-cooling and big ceiling fans can help save energy. As identified in many Energy Treasure Hunt In-Plant Trainings by the BP program, these fans had been found on when not needed. A good rule of thumb is that, given the electricity rate of $\$ 0.1 / \mathrm{kWh}$ and the load factor of $90 \%$, the annual energy cost is about $\$ 550 / \mathrm{hp}$.

\subsubsection{Installing UVGI Lamps in the Air Streams}

Some partners noted that they have installed Ultraviolet Germicidal Irradiation (UVGI) lamps in the air stream to help reduce the virus concentration in the recirculated air.

Energy Note: UVGI lamps use electricity (about 7.2 W/1,000 CFM) and add a small amount of cooling load, which causes some energy penalty. A good rule of thumb is that, given the electricity rate of $\$ 0.1 / \mathrm{kWh}$ and the load factor of $90 \%$, the annual energy cost penalty from the lamps and extra cooling loads is about $\$ 10 / 1,000$ CFM [5].

\subsubsection{Using Heat Pipe ERUs}

Several partners mentioned that they are replacing existing enthalpy wheel ERUs with the heat pipe type in central air-handling units. Enthalpy wheel and heat pipe ERUs can preheat and precool outdoor air and partially offset the energy penalty from providing more outdoor air during the pandemic. However, unlike in enthalpy wheel ERUs, outdoor air and exhaust air streams never share pathways in heat pipe ERUs, which can significantly reduce or even eliminate cross-contamination [6].

Energy Note: Enthalpy wheel ERUs can recover both sensible and latent heat, but heat pipe ERUs typically can only recover sensible heat. The total energy recovery effectiveness of enthalpy wheel ERUs is about $75 \%$ to $85 \%$, but the total energy recovery effectiveness of heat pipe ERUs is only about $45 \%$ to 
$65 \%$. Compared with enthalpy wheel ERUs, using heat pipe ERUs may lose about $20 \%$ energy recovery efficiency [6].

\section{SUMMARY}

Screening for symptoms, maintaining physical distance, sanitizing surfaces, wearing appropriate face masks, maintaining good personal hygiene, and reconfiguring HVAC air management are the major activities that the BP partners have implemented to mitigate COVID-19. This article shares some specific practices that BP program partners have implemented for these activities. The energy impact of some practices has also been discussed and some rules of thumb have been provided to estimate energy penalties.

\section{REFERENCES}

1. DOE AMO. Better Plants Program Progress Report 2020.

2. W. Guo, T. Wenning, S. Nimbalkar, E. Levine, \& B. Lung. Industrial Energy Management During a Pandemic: What We Have Learned from DOE Better Plants Program Partners. ORNL Technical Report. ORNL/TM-2020/1778. OSTI Identifier 1671403. https://doi.org/10.2172/1671403

3. Dwyer Instruments. DF Series Pleated Filters, (2016)

4. US DOE. Specification for HEPA Filters Used by DOE Contractors, (2015).

5. W.J. Kowalski, B. William. UVGI Design Basics for Air and Surface Disinfection, Heating, Piping, and Air Conditioning. (2000) 100-110.

6. M. Rabbia, G. Dowse. Energy Recovery Ventilation, Carrier Corporation, 2000, https://www.shareddocs.com/hvac/docs/1001/Public/03/WP005.pdf (last accessed Oct 10, 2020). 